\title{
Correlation of Intravenous Administration of Iodinated Nonionic Contrast Agents with Contrast-Induced Nephrotoxicity in Sedated Dogs
}

\author{
RADU LACATUS ${ }^{1}$, CRISTIAN PAUL POPOVICI ${ }^{2}$, ELENA GAVRILAS ${ }^{4}$, RAZVAN CODEA ${ }^{2}$, \\ LAURA CONDOR $^{1}$, MARIANA TATARU ${ }^{1}$, IONEL PAPUC ${ }^{1}$, ADELA CRISTINA LAZAR ${ }^{3}$, \\ MALINA POPA $^{6}$, ROBERT CRISTIAN PURDOIU ${ }^{1 *}$, MIHAI MUSTEATA ${ }^{5}$ \\ ${ }^{1}$ University of Agricultural Sciences and Veterinary Medicine, Faculty of Veterinary Medicine, Department III Paraclinical \\ Sciences, 3-5 Calea Manastur, 400372, Cluj-Napoca, Romania \\ ${ }^{2}$ University of Agricultural Sciences and Veterinary Medicine, Department IV Clinical Sciences, 3-5 Calea Manastur, \\ 400372, Cluj-Napoca, Romania \\ 3"Iuliu Hatieganu" University, Faculty of Dental Medicine, Department of Oral Rehabilitation, Health and Management \\ of Dental office, 4 Louis Pasteur Str., 400349, Cluj-Napoca, Romania \\ ${ }^{4}$ University of Agricultural Sciences and Veterinary Medicine "Ion Ionescu de la Brad", Faculty of Veterinary Medicine, \\ Department of Semiology and Radiology, 8 Mihail Sadoveanu Alley, 700489, Iași, Romania \\ ${ }^{5}$ University of Agricultural Sciences and Veterinary Medicine "Ion Ionescu de la Brad", Faculty of Veterinary Medicine, \\ Department of Internal medicine, 8 Mihail Sadoveanu Str., 700489, Iași, Romania \\ "Victor Babes" University, Faculty of Dental Medicine, 2 Eftimie Murgu Sq., 300041, Timisoara, Romania
}

\begin{abstract}
One of most accessible physical method of investigation in veterinary medicine is represented by the radiographic study. The contrast agents are used in veterinary radiology to highlight the anatomical structures. The contrast agents can absorb X-Ray and are used in special radiological procedures such as angiography, urography, myelography, contrast Computed Tomography or evaluation of gastrointestinal tract. The aim of the this paper was to perform a retrospective study to identify the complications associated with non-ionic contrast agents administration in dogs that undergo contrast radiography or contrast CT examination. Between January 2016 and January 2018, we selected a number of 234 dogs that were evaluated using contrast agents procedures (contrast radiography, contrast CT). A number of 192 cases had blood analysis before and after contrast administration and were included in the study.
\end{abstract}

Keywords: contrast-induced nephropathy, contrast-induced acute kidney injury, nephrotoxicity, contrast agents, dogs

One of most accessible physical method of investigation in veterinary medicine is represented by the radiographic study. The rapid development of sciences made the radiography a routine procedure in the diagnostics of a various pathology and introduce also the Computed Tomography (CT) as a diagnostic tool for the veterinarian. Iodinated contrast agents are use in special radiological procedures because of their high-contrast density, this property makes these substances useful in visualization of a certain soft structures, making the contrast agents the most frequently used drugs in veterinary radiology $[1,2]$. The downside of using those substances is the supposed renal toxicity.

The contrast agents can absorb X-Ray and are used to visualize the urinary tract (urography), to evaluate the vascular structures (angiography, phlebography), the spinal cord (myelography), in organ evaluation using contrast CT or for gastrointestinal tract. It derives their structure from iodine or barium sulfate and do not emit radiation. According to their structure, the contrast agents, are ionic or non-ionic [2]. Those are organic compound, monomeric or dimeric with low or high osmolarity, with benzene structures and variable content of iodinated compound. The non-ionic contrast agents have a low osmolarity (600-850 mOsm $/ \mathrm{kg}$, two to three times plasma osmolality) compared with ionic contrast agents $(1,500-1,800 \mathrm{mOsm} / \mathrm{kg}$, five to eight times plasma osmolality) [1]. The ionic high osmolarity contrast agents present an increased risk of an alternated heart rate and renal toxicity, being more irritative compared with non-ionic low osmolarity contrast agents [3]. The ionic and non-ionic iodine contrast agents can be administered intravenously, in angiography, urography, phlebography. For intramedullary or intra-articular administration are used non-ionic iodine contrast agents and for oral administration are used barium sulfate compound.

The most commonly used in veterinary radiology, for contrast studies, are iodinated non-ionic contrast agents (table 1). Intravenous administration of contrast agents is associated with several side effects from which the most important is contrast induces acute kidney injury (CI-AKI) (also known as contrast induce nephropathy or nephrotoxicosis - CIN). CI-AKI is defined as an elevation of serum creatinine (SC) of over $25 \%$ or $\geq 0.5 \mathrm{mg} / \mathrm{dl}$ from baseline within $24-48 \mathrm{~h}$ post contrast agents administration that cannot be attributed to other causes [4-6].

*email: robert.purdoiu@usamvcluj.ro

REV.CHIM (Bucharest) $\bullet 70 \diamond$ no. $12 \downarrow 2019$ 
Table 1

CHEMICAL PROPERTIES OF MOST COMMONLY USE CONTRAST AGENTS IN VETERINARY MEDICINE

\begin{tabular}{|c|c|c|c|c|c|}
\hline Contrast Agent & Composition & Chemical formula & Iodine content & Osmolarity & Type \\
\hline $\begin{array}{l}\text { Iopromide } \\
\text { (Ultravist 370) }\end{array}$ & $\begin{array}{l}\text { Monomer } \\
\mathrm{C}_{18} \mathrm{H}_{24} \mathrm{I}_{3} \mathrm{~N}_{3} \mathrm{O}_{8}\end{array}$ & & $370 \mathrm{mg} / \mathrm{dl}$ & Low & Non-ionic \\
\hline $\begin{array}{l}\text { Ioversol (Optiray } \\
350)\end{array}$ & $\begin{array}{l}\text { Monomer } \\
\mathrm{C}_{18} \mathrm{H}_{24} \mathrm{I}_{3} \mathrm{~N}_{3} \mathrm{O}_{9}\end{array}$ & & $350 \mathrm{mg} / \mathrm{dl}$ & Low & Non-ionic \\
\hline $\begin{array}{l}\text { Iohexol } \\
\text { (Omnipaque 350) }\end{array}$ & $\begin{array}{l}\text { Monomer } \\
\mathrm{C}_{19} \mathrm{H}_{26} \mathrm{I}_{3} \mathrm{~N}_{3} \mathrm{O}_{9}\end{array}$ & & $350 \mathrm{mg} / \mathrm{dl}$ & Low & Non-ionic \\
\hline
\end{tabular}

\section{Experimental part}

\section{Materials and methods}

The aim of the paper was to perform a retrospective study to identify the complications associated with non-ionic contrast agents administration in dogs that undergo contrast radiography or contrast CT examination. Between January 2016 and January 2018, we selected a number of 234 dogs that were evaluated using contrast agents procedures (contrast radiography, contrast CT). From the initial number of these patients, 42 were excluded because they did not have blood analysis or the contrast study was administered orally. The remaining of 192 cases, in 167 patients the contrast agent was administered intravenous and in 25 patients the contrast agent was administered intrarachidian.

The age median was 5 years (with a minimum of 1 year and a maximum of 11 years), age mean and standard deviation of $4.82 \pm 2.47$ years of age. Of the total patient included in the study, the weight median was $9 \mathrm{~kg}$ (with a minim of $3 \mathrm{~kg}$ and a maxim of $26 \mathrm{~kg}$ ) and the mean weight was $11.44 \pm 6.23 \mathrm{~kg}, 52.08 \%(\mathrm{~N}=100)$ had a mean weight of $6.73 \pm 2.34 \mathrm{~kg}$ (under $10 \mathrm{~kg}$ ) and $47.91 \%(\mathrm{~N}=92)$ had a mean weight of $16.57 \pm 4.97 \mathrm{~kg}$ (over $10 \mathrm{~kg}$ ). Of the total of 192 patients, 87 were males and 105 females. A variety of breeds was represented in this study, with no breed being substantially overrepresented.

Contrast agents for this study were represented by Optiray 350 (producer Typo HealthCare), Ultravist 350 (Bayer Healthcare) and Omnipaque 350 (GE Healthcare). All the patients were sedated before the contrast study using tailored anesthesia protocols, Diazepam (Gedeon Richter, Romania) $0.25 \mathrm{mg} / \mathrm{kg}$ in combination with Ketamine (Romvac, Romania) $1 \mathrm{mg} / \mathrm{kg}$ and Propophol (APP Pharmaceuticals) to effect.

The pulse, temperature, respiratory frequency and blood analysis were performed before and after contrast agent administration up to 24 hours. The blood parameters evaluated were represented by blood urea nitrogen, creatinine, alkaline phosphatase, $\mathrm{Na}, \mathrm{K}$ and liver enzymes. All dogs were hemodynamically supported with IV fluids after contrast agent administration.

The descriptive statistic was performed using Excel Descriptive Tools, we calculated the median, mean values and standard deviation.

\section{Results and discussions}

From the total 192 cases, the contrast agents administered included Iopromide (Ultravist 370) in 38\% of cases (73 administration), Ioversol (Optiray 350) in 30\% of cases (57 administration) and Iohexol (Omnipaque 350) in 32\% of cases (62 administration). The average consumption of contrast agents was $20.47 \pm 13.62 \mathrm{ml} /$ procedure, with a median of $18 \mathrm{ml} /$ procedure (range $0.6-52 \mathrm{ml} /$ procedure). The administered dose of contrast agent was $2 \mathrm{ml} / \mathrm{kg}$ for intravenous administration and $0.2 \mathrm{ml} / \mathrm{kg}$ for intrarachidian administration.

Changes in the heart (HR) and respiratory frequency (RF) were presented in $2(1.2 \%)$ cases after contrast agent administration and were corelated with preexistent condition (pulmonary lesions). Other side effects encountered after intravenous contrast agents administration in 167 cases were represented by vomiting ( 3 cases $-1.79 \%$ out of 167 patients), tremor, severe muscle spasms, agitation and vocalization ( 1 case $-0.59 \%$ out of 167 patient), all the patient were subsequently diagnosticated with other pathologies. In 2 cases that presented vomiting, ultrasound and CT examination reveal intraabdominal masses, 1 case was diagnosticated with chronic kidney pathology and 1 patient was diagnosticated with cerebellar lesion due to otitis. Other sporadic changes of the heart and respiratory frequency were encounter, being related with the anesthetic administration. 
From 25 cases where the contrast was administering intrarachidian, 1 case (4\%) presented seizures at 2 hours post contrast administration. The seizures were related with a change in the flow of cerebrospinal fluid; the patient fully recovered after 2 days of treatment (table 2).

Table 2

ADVERSE REACTION AFTER IODINATED CONTRAST ADMINISTRATION

\begin{tabular}{|c|c|c|c|}
\hline No of Cases & Adverse reaction & $\begin{array}{c}\text { Contrast } \\
\text { administration }\end{array}$ & Obs \\
\hline $2(1.2 \%)$ & $\begin{array}{c}\text { Increased HR, } \\
\text { increased RF }\end{array}$ & Intravenously & $\begin{array}{c}\text { Focal area of } \\
\text { pulmonary fybrosis }\end{array}$ \\
\hline $2(1.2 \%)$ & vomiting & Intravenously & $\begin{array}{c}\text { Spleen tumor with } \\
\text { abdominal metastasis }\end{array}$ \\
\hline $1(0.59 \%)$ & vomiting & Intravenously & $\begin{array}{c}\text { Chronic kidney } \\
\text { pathology }\end{array}$ \\
\hline $1(0.59 \%)$ & $\begin{array}{c}\text { tremor, severe } \\
\text { muscle spasms, } \\
\text { agitation and } \\
\text { vocalization } \\
\text { seizures }\end{array}$ & Intravenously & $\begin{array}{c}\text { Cerebellar lesions } \\
\text { due to otitis }\end{array}$ \\
\hline $1(4 \%)$ & Intrarachidian & Cerebral \\
\hline
\end{tabular}

Of the total cases from this study, changes in the blood biochemistry was evident in 15 cases (7.8\%). At 24 hours post contrast administration increased values were determined for: serum creatinine (SC $2.2 \pm 0.58 \mathrm{mg} / \mathrm{dl}$, normal 0.6$2.0 \mathrm{mg} / \mathrm{dl}$ ), gamma glutamyl-transferase (GGT 108 $\pm 23.1 \mathrm{IU} / \mathrm{l}$, normal 2-10 IU/l), blood urea nitrogen (BUN $59 \pm 1.57$ $\mathrm{mg} / \mathrm{dl}$, normal 8-29 mg/dl), alkaline phosphatase (ALP 589 $\pm 21.45 \mathrm{IU} / \mathrm{l}$, normal 12-121 IU/L), Aspartate Aminotransferase (AST/GOT 87 \pm 5.48 IU/l, normal 16-54 IU/l), Alanyl Aminotransferase (ALT/GPT 199 \pm 14.58 IU/l, normal 18-86 IU/l) and $\mathrm{K}(7.38 \pm 1.6 \mathrm{mEq} / \mathrm{L}$, normal 3.5-5.5 mEq/L) (table 3).

Table 3

MEAN VALUES AND STANDARD DEVIATION OF THE MODIFIED BIOCHEMICAL PARAMETERS AFTER IODINATED CONTRAST AGENTS ADMINISTRATION IN 15 CASES

\begin{tabular}{|l|l|l|}
\hline Parameters & Registere values & Limits (16) \\
\hline Serum creatinine (SC) & $2.2 \pm 0.58 \mathrm{mg} / \mathrm{dl}$ & $0.6-2.0 \mathrm{mg} / \mathrm{dl}$ \\
\hline gamma glutamyl-transferase (GGT) & $08 \pm 23.1 \mathrm{IU} / \mathrm{l}$ & $2-10 \mathrm{IU} / \mathrm{l}$ \\
\hline Blood urea nitrogen (BUN) & $59 \pm 1.57 \mathrm{mg} / \mathrm{dl}$ & $8-29 \mathrm{mg} / \mathrm{dl}$ \\
\hline Alkaline phosphatase (ALP) & $589 \pm 21.45 \mathrm{IU} / 1$ & $12-121 \mathrm{IU} / \mathrm{L}$ \\
\hline $\begin{array}{c}\text { Aspartate Aminotransferase } \\
\text { (AST/GOT) }\end{array}$ & $87 \pm 5,48 \mathrm{IU} / 1$ & $16-54 \mathrm{IU} / \mathrm{l}$ \\
\hline $\begin{array}{c}\text { Alanyl Aminotransferase } \\
(\text { ALT/GPT) }\end{array}$ & $199 \pm 14,58 \mathrm{IU} / \mathrm{l}$ & $18-86 \mathrm{IU} / \mathrm{l}$ \\
\hline Potassium (K) & $7.38 \pm 1,6 \mathrm{mEq} / \mathrm{L}$ & $3.5-5.5 \mathrm{mEq} / \mathrm{L}$ \\
\hline
\end{tabular}

Unwanted side effects of the contrast agents administration can be acute, delayed or systemic. Acute reaction is most common (70\%), can occur in the first 5 minutes after administration and can vary from mild to severe. Mild reaction are represented by itching or mild cutaneous irritation, and the severe reaction can manifest as allergic effect, or anaphylactic reaction [1]. Delayed effects are uncommon and can appear between 1 hour and 7 days post contrast administration. Systemic effect represents a separate category and include complication such as contrast induced nephropathy (CIN) [3]. In human medicine, CIN is the third most common acquired acute renal injury, representing $12 \%$ of the cases, with a incidence between 0 and 24\% depending on the patient risk [6-8]. It is defined as a transient and reversible form of acute renal failure [9].

In veterinary medicine due to low incidence of clinically relevant injury following contrast agents administration, the nephrotoxicity following contrast administration can be challenging to evaluate. The studies show an incidence of $7.6 \%$ with clinically relevant kidney injury in only $2.2 \%$ of contrast administrations [10].

Studies performed by Katzberg (2007) and Dong (2012) indicate an increased risk of CIN in case of intraarterial administration of iodinated contrast agents compared with intravenous administration $[11,12]$. More recent studies show limited to no demonstrable apparition of CIN associated with intravenous administration of contrast agents [13-15].

Contrast agents are filtered by the kidney causing short term renal vasodilatation followed by renal vasoconstriction, that will produce decrease in renal blood flow and glomerular filtration rate. Increased effect of angiotensin II, adenosine, and endothelin will produce constriction of the vasa recta. Changes in osmolarity will produce increased diuresis and increased sodium reabsorption, producing increased $\mathrm{O}_{2}$ consumption and medullary hypoxia [1,17] Direct injury by the contrast agents on the endothelial cells will lead to production of reactive oxygen species, that will reduce the nitric oxide, contributing to vasa recta constriction and medullary hypoxia [17]. 
Changes in BUN and SC level are related with the renal hypoxia and early signs of CIN, although only those two parameters alone are not a direct indication of CIN [18]. Increased values of GGT and ALP are indicative for the tubular changes produced by the contrast agents, therefore being involve in the pathogenesis of CIN [19, 21]. Research conducted by Sirken in 2004 indicate that iodinated contrast agents administration result in hypertonic hyponatremia through a dual effect of exogenous fluid dilution and translocation. The fluid translocated from intracellular to extracellular spaces may lead to a decrease in sodium, chloride, and bicarbonate levels developing hyperkalemia caused by solvent drag and/or passive diffusion [22].

The median age for the patient that presented signs of CIN was 9 years (range between 7 and 11 years) with a mean age of $8.77 \pm 1.28$ years. The patients manifesting signs of CIN had previous history of renal or hepatic pathologies.

\section{Conclusions}

The percent of CIN in dogs is low (7.8\%) after iodinated contrast administration, confirming data's from literature. $\mathrm{CIN}$ is most likely to appear in older patients with subsequent kidney pathology. An early predictor signs of CIN can be obtained by correlation of changes in SC, GGT, ALP and K.

\section{References}

1. ANDREUCCI M, FAGA T, SERRA R, DE SARRO G MA. Update on the renal toxicity of iodinated contrast drugs used in clinical medicine. Drug Heal Patient Saf. 2017;9:25-37.

2. CINTEZA E, BALGRADEAN M, FILIP C, DUICA G, NICOLAE G, NICOLESCU A, et al. Iodinated contrast media in pediatric cardiac angiography nephrotoxic risk evaluation. Rev Chim (Bucharest), 69, no. 2, 2018, p. 511-4.

3. POLLARD R, DVM, PUCHALSKI SM PP. Hemodynamic and serum biochemical alterations associated with intravenous administration of three types of contrast media in anesthetized dogs. AJVR. 2008;69(10):1268-73.

4. MORCOS SK. Contrast media-induced nephrotoxicity-questions and answers. Br J Radiol. 1998;71(844):357-365.

5. McCULLOUGH PA, SOMAN SS. Contrast-induced nephropathy. Crit Care Clin. 2005;21(2):261-280.

6. MOHAMMED NMA, MAHFOUZ A, ACHKAR K, RAFIE IM HR. Contrast-induced Nephropathy. Hear Views. 2013;14(3):106-116.

7. HOU SH, BUSHINSKY DA, WISH JB, COHEN JJ HJ. Hospital-acquired renal insufficiency: a prospective study. Am J Med. 1983;74(2):243-

8. PERRIN T, DESCOMBES E CS. Contrast-induced nephropathy in invasive cardiology. Swiss Med Wkly. 2012;142:w13608.

9. McCULLOUGH PA, ADAM A, BECKER CR, DAVIDSON C, LAMEIRE N, STACUL F TJ. Epidemiology and prognostic implications of contrast-induced nephropathy. Am J Cardiol. 2006;98(6A):5K-13K.

10.GOIC JB, KOENIGSHOF AM ML, KLINGER AC BM. A retrospective evaluation of contrast-induced kidney injury in dogs (2006-2012). J Vet Emerg Crit Care. 2016;26(5):713-9.

11.KATZBERG RW BB. Risk of iodinated contrast material-induced nephropathy with intravenous administration. Radiology. 2007;243(3):622628.

12. DONG M, JIAO Z, LIU T, GUO F, LI G. Effect of administration route on the renal safety of contrast agents: a meta-analysis of randomized controlled trials. J Nephrol. 2012;25(3):290-301.

13. NEWHOUSE JH, KHO D, RAO QA SJ. Frequency of serum creatinine changes in the absence of iodinated contrast material: implications for studies of contrast nephrotoxicity. AJR Am J Roentgenol. 2008;191(2):376-382.

14. KATZBERG RW NJ. Intravenous contrast medium-induced nephrotoxicity: is the medical risk really as great as we have come to believe? Radiology. 2010;256(1):21-28.

15. McDONALD JS, MCDONALD RJ, COMIN J, WILLIAMSON EE, KATZBERG RW, MURAD MH KD. Frequency of acute kidney injury following intravenous contrast medium administration: a systematic review and meta-analysis. Radiology. 2013;267(1):119-28.

16. VADEN S L, KNOLL J S, SMITH Jr F W.K TL. Blackwell's Five-Minute Veterinary Consult: Laboratory Tests andDiagnostic Procedures: Canine \& Feline. 2009.

17. ANDREUCCI M, FAGA T, PISANI A, SABBATINI M MA. Pathogenesis of acute renal failure induced by iodinated radiographic contrast media. Austin J Nephrol Hypertens. 2014;1(1):1005.

18. WACKER-GUßMANN A, BÜHREN K, SCHULTHEISS C, BRAUN S L, PAGE S, SAUGEL B, SCHMID S, MAIR S, SCHOEMIG A, SCHMID R M. HW. Prediction of Contrast-Induced Nephropathy in Patients With Serum Creatinine Levels in the Upper Normal Range by Cystatin C: A Prospective Study in 374 Patients. Am J Roent [Internet]. 2014;202:452-458. Available from: https://www.ncbi.nlm.nih. gov/pubmed/24450691

19. DONADIO C, TRAMONTI G, LUCCHESI A, GIORDANI R, LUCCHETTI A BC. Gamma-glutamyltransferase is a reliable marker for tubular effects of contrast media. Ren Fail. 1998;20(2):319-24.

20. KARABULUT A, SAHIN I, ILKER AVCI I, OKUYAN E, DOGAN Z, UZUNLAR B, CAKMAK M GM. Impact of serum alkaline phosphatase level on the pathophysiologic mechanism of contrast-induced nephropathy. Kardiol Pol. 2014;72(10):977-82.

21. OTELEA, MR, TRENCHEA, M, ARGHIR, OC, VELESCU, L, DANTES, E, BECHIR, ES, ELSAAFIN, M, RASCU, A, Rev. Chim (Bucharest), 69, no. 1, 2018,p. 282-285.

22. SIRKEN G, RAJA R, GARCES J, BLOOM E FP. Contrast-induced translocational hyponatremia and hyperkalemia in advanced kidney disease. Am J Kidney Dis. 2004;44(6):1127.

$\overline{\text { Manuscript received: } 14.12 .2019}$ 